\section{Functional structure of battery drive for self-propelled mining rig used in room-pillar ore exploitation system}

\author{
Tomasz Szurlej, Lesław Ostapów, Paweł Mendyka \\ Mine Master Ltd., Poland
}

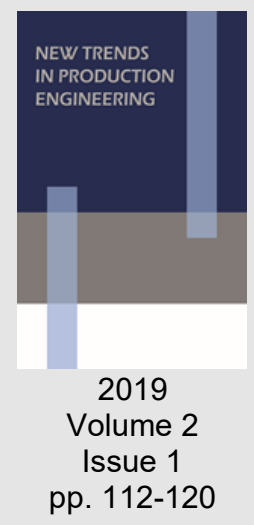

Date of submission to the Editor: 05/2019

Date of acceptance by the Editor: 07/2019

\title{
INTRODUCTION
}

Self-propelled underground machinery with electric drives are used in underground mining due to a number of advantages of such a drive, among others no emission of harmful gases into the mine atmosphere, higher efficiency or a smaller amount of generated heat. The main disadvantage of currently used electrical solutions of drilling rig drives is the low maneuverability of the machine, due to the need to unwind an electric cable at the back of the rig or the use of pantograph solutions. In the hard rock mining, the classical battery-powered machinery have not found a wider use due to their general inferior operational parameters, mainly due to the low energy density of the lead-acidic batteries.

In many aspects, the most advantageous drive system of drilling rig machines is an electric system powered from a mobile power source with high power density and an acceptable charging time. This requirement is met by a battery supply system using modern battery cells. At present, none of the major producers of drilling and anchoring vehicles produce series of such machines with electric drive.

On the basis of the analysis of the conditions of drilling works currently conducted in hard rock metal ore mines, a number of assumptions for the synthesis of the battery structure of the driving drive for drilling and anchoring vehicles were developed. According to these assumptions:

- The electric drive motor should have a similar nominal power rating than the currently used combustion engine; depending on individual application, power of electric drive can be little bit lower or higher than power of diesel engine,

- The battery drive should allow autonomous movement of the rig for a period of at least one hundred and ten minutes per working shift; typically it is sixtyfive minutes in polish hard rock mining conditions.

- Operations related to drilling holes for a drilling rig take on average about one hundred and twenty minutes, up to a maximum of one hundred and eighty. 
Taking into account technological operations, part of the remaining time (about ninety minutes per shift) can be used to charge the drive batteries from the mine electrical network, again taking into considerations polish hard rock mining conditions.

- The average slope of the routes covered by the drilling rig sare about $2-3^{\circ}$, on average, fluctuating up to $6^{\circ}$. Assuming no deterioration in the traction characteristics of electrically driven vehicles with respect to vehicles with internal combustion engines, the designed driving system should allow for climbing hills with an inclination of up to $15^{\circ}$.

- The electric drive must be suitable for operation at an ambient temperature of $43^{\circ} \mathrm{C}$ on average and ranging from $25^{\circ} \mathrm{C}$ to $45^{\circ} \mathrm{C}$.

- The drilling rig should be able to move at least 6000 meters on one battery charge to maintain the mobility of the diesel propelled rig.

- The average velocity of nowadays used diesel vehicles in hard rock mines is approx. $6.5-8 \mathrm{~km} / \mathrm{h}$. Assuming a similar technological cycle of the rig's work, the electric drive should allow to achieve similar average velocities.

\section{UNDERGROUND DRILLING RIG STRUCTURE}

As part of the ongoing research project, the battery drive was applied in a modified drilling rig produced by Mine Master company, based on the construction marked as Face Master 1.7L. Overview of this type of boring rig is shown in Figure 1 (minemaster.eu, 2019).

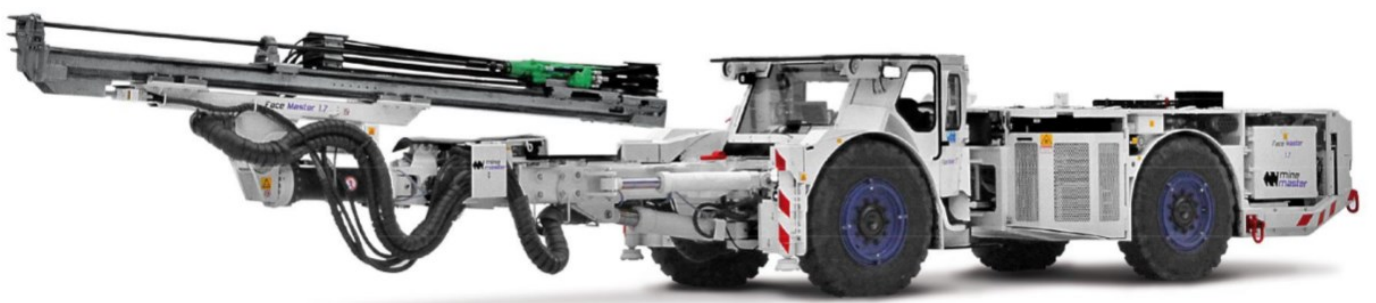

Fig. 1 Mine Master 1.7L drilling rig - machine designated for installation of battery drive

A characteristic feature of this company's rigs is the hydrostatic drive. It consists in placing hydraulic motors in each of the wheels, powered from the central pump system, which in turn is driven from the main engine of the vehicle. Such a solution enables smooth control of the machine's operation and ensures a large hydraulic transmission ratio, while maintaining small dimensions of the entire drivetrain (Derlukiewicz, D., Karliński, J., 2004). This solution has been successfully tested and is used in many mines around the world. Schematic structure of the hydrostatic drive is shown in Figure 2.

The main parameters of the described drilling rig discussed are summarized in Table 1. It is worth noting the use of much higher absorptive capacity of hydraulic motors in relation to the efficiency of pumps allows to obtain a large transmission ratio without the need of using costly and susceptible to failures mechanical transmissions (Derlukiewicz, D., Karliński, J., 2012). 


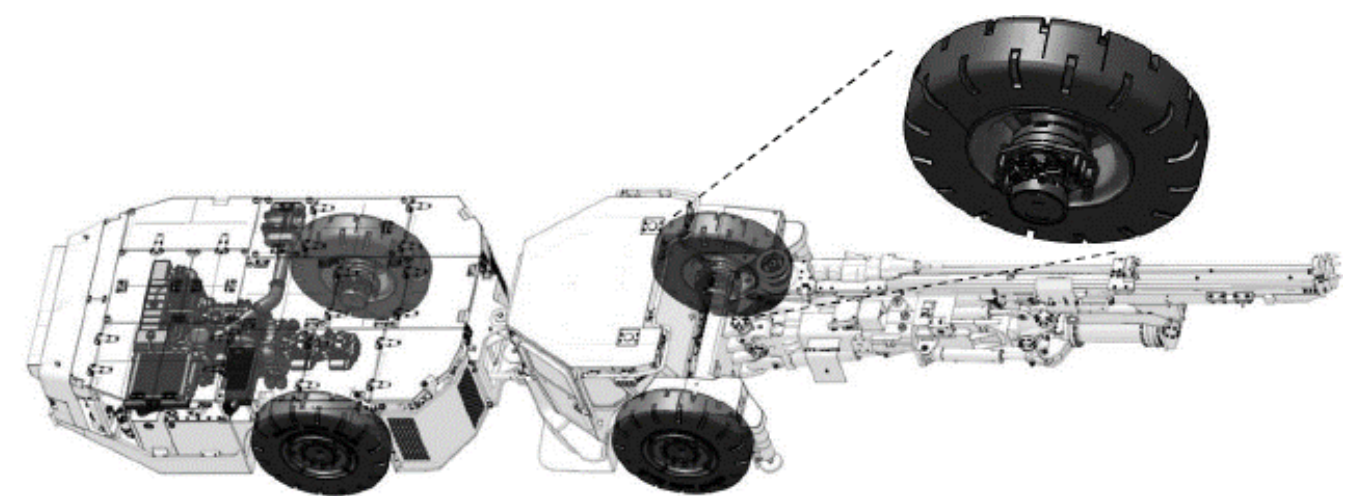

Fig. 2 The idea oh hydrostatic drive with hydraulic motor installed in each rig wheel

As part of the proposed solution, it was assumed that the electric motor power of the prototype structure would have a little bit greater nominal power than nowadays used internal combustion engine. In comparison with the diesel engine, such assumption will result in improved traction characteristics of the rig.

Table 1 Main parameters of Mine Master 1.7L drilling rig

\begin{tabular}{|c|c|}
\hline Drilling rig parameter & Value \\
\hline Vehicle mass [Mg] & 21.5 \\
\hline Load on the front axle [Mg] & 11.5 \\
\hline Load on the rear axle $[\mathrm{Mg}]$ & 10 \\
\hline Outer wheel diameter [m] & 1.24 \\
\hline Cross-section area $\left[\mathrm{m}^{2}\right]$ & 4.5 \\
\hline Working face area $\left[\mathrm{m}^{2}\right]$ & 64 \\
\hline Wheelbase [m] & 3.5 \\
\hline unit hydraulic capacity of front wheel motors $\left[\mathrm{cm}^{3} / \mathrm{rev}\right]$ & 4198 \\
\hline unit hydraulic capacity of back wheel motors [ $\left.\mathrm{cm}^{3} / \mathrm{rev}\right]$ & 2812 \\
\hline Front axle drive pump performance $\left[\mathrm{cm}^{3} / \mathrm{rev}\right]$ & $0-100$ \\
\hline Rear axle drive pump performance $\left[\mathrm{cm}^{3} / \mathrm{rev}\right]$ & $0-100$ \\
\hline Max. hydraulic pressure [MPa] (safety valves) & 10 \\
\hline power of the internal combustion engine [kW] & 90 \\
\hline electric motor power $[\mathrm{kW}]$ & 140 \\
\hline general efficiency of the drive system (without motor) & $\eta=0.85$ \\
\hline
\end{tabular}

\section{BATTERY DRIVE STRUCTURE}

The drive system with battery power supply is characterized by greater mechanical simplicity than the one using internal combustion engine, while electrical and control systems are much more advanced. The driving unit is in most cases a DC electric motor in the case of older solutions, or more modern type of electric motor (for example deep grooved, reluctance, PMSM solution) the case of usage of modern batteries with a suitable driver. The PMSM drive (permanent magnet synchronous motor) characteristics are best suited to the drive of machines and vehicles, because high torque is achieved, among others, at the moment of start-up - when the demand for it is greatest. The use of an electronic speed control system allows to abandon complicated and expensive mechanical or mechanical-hydraulic shifting systems. The lack of a unwind power cable in battery solutions significantly increases the maneuverability and applicability of this type of machine.

The main parts of the electric drive system are (after Kotwica, K., Mendyka, P., Czajkowski, A., Ostapow, L., Kozlowski, A., 2017): 
- Electric motor - the main part of the electric drive, connected with other parts of drivetrain (axes, clutches, wheels etc.) Much higher efficiency of electric motor (compared to combustion engine) gives many advantages, such as heat and noise reduction or less energy consumption.

- Power Train controller - the module connected with driver's panel, responsible for electric motor control.

- Battery - main source of electric motor energy. Batteries are accessible in many different kinds and technologies, for example lithium-ion batteries are made in graphite, lithium titanite, hard carbon, tin/cobalt alloy and silicon/carbon technologies)

- Battery Monitoring Unit - controller responsible for proper battery work; it transfers information about battery status to on board systems, safety devices and driver displays.

- Battery Control Unit - element responsible for proper battery charge. Many types of modern batteries are overcharge sensitive; one of the battery control unit functions is to prevent overcharge by separation of charging circuit from battery when energy reaches battery limit.

- External or internal Charger - device responsible for delivering external energy to drive system; in underground mine external charger has to be equipped with DC/DC converter, from standard mine voltage (usually 500 or $1000 \mathrm{~V}$ ) to voltage suitable for battery charging; it could be mounted inside on outside the rig.

- Thermal Management system - very important component, especially in very warm conditions. Maintaining proper charging and work temperature of electronic circuits is a key factor for keeping them from premature degradation and for ensuring proper operation.

- DC/DC converter - provides lower voltage (usually $24 \mathrm{~V}$ ) for safety and auxiliary systems.

Schematic representation of such system is shown on Figure 3.

Underground Rig Battery Drive System

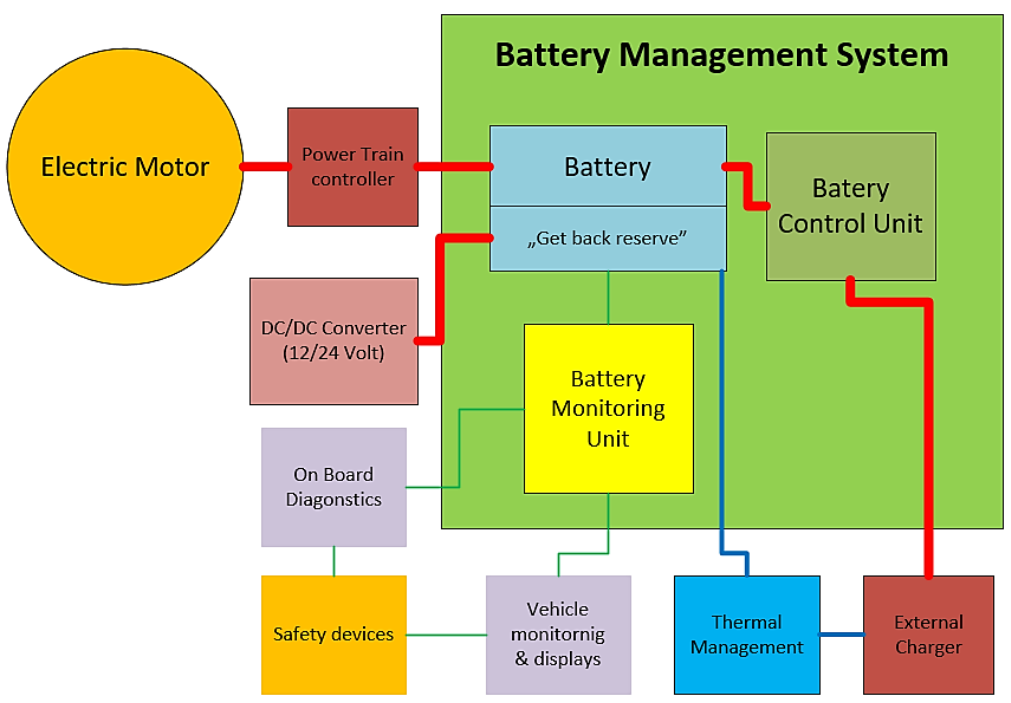

Fig. 3 Mining rig battery drive system components 
One of the basic questions about electric drives is the type of batteries to be used. In practice, there is no simple answer to the question of which batteries are best for use in mining machines, although essentially two types seem to be the most advantageous: lithium-ion batteries and nickel-sodium batteries (Van Mierlo, J., Maggetto, G., \& Lataire, P., 2006). However, it should be noted that there are different types and technologies of making these two groups of batteries, hence the comparison of individual types of batteries is complex and should be done separately for each new application. Basic, comparative information about battery types is included in Table 2 .

Table 2 Comparison of batterytypes

\begin{tabular}{|l|c|c|c|c|c|}
\hline \multicolumn{1}{|c|}{$\begin{array}{c}\text { Type } \\
\text { of battery }\end{array}$} & $\begin{array}{c}\text { Lithium } \\
\text { lon }\end{array}$ & $\begin{array}{c}\text { Sodium } \\
\text { nickel }\end{array}$ & Bromide & $\begin{array}{c}\text { Gel Lead } \\
\text { Acid }\end{array}$ & $\begin{array}{c}\text { Salt } \\
\text { Water }\end{array}$ \\
\hline $\begin{array}{l}\text { Operating } \\
\text { temperature }\left[{ }^{\circ} \mathrm{C}\right]\end{array}$ & +5 to +35 & -40 to +50 & +10 to +45 & +5 to +40 & -5 to +40 \\
\hline $\begin{array}{l}\text { Draw-down } \\
\text { power [kW] }\end{array}$ & 2 & 7.6 & 3.6 & $\begin{array}{c}5 \mathrm{~kW} \\
25 \% \text { depth } \\
\text { of discharge }\end{array}$ & $\sim 0.8 \mathrm{~kW}$ \\
\hline $\begin{array}{l}\text { Battery } \\
\text { degradation } \\
\text { after } 10 \text { years } \\
\text { \% }\end{array}$ & 40 to 50 & 0 & 0 & 50 to 70 & 30 \\
\hline $\begin{array}{l}\text { Mass of } 20 \mathrm{kWh} \\
\text { battery [kg] }\end{array}$ & $120 \times 3$ & $104 \times 2$ & $240 \times 2$ & $54 \times 24$ & $118 \times 12$ \\
\hline Charging time & fast & fast & Fast & slow & slow \\
\hline Energy density & medium & highest & High & medium & lowest \\
\hline
\end{tabular}

Source: (based on Kotwica, K., Mendyka, P., Czajkowski, A., Ostapow, L., Kozlowski, A., 2017)

\section{ESTIMATION OF DRIVE CHARACTERISTICS OF BATTERY DRIVEN DRILLING RIG}

The type of motor used in the drive of the drilling rig has a significant impact on its technical parameters. The type of engine used affects both the basic parameters such as pull force, gradeability, operating times of the working system, etc., as well as the amount of energy consumed by the machine.

All working machines operating in conditions of underground hard rock mines are characterized by the fact that their loads are not constant over a longer period of time, but they change many times (often cyclically) during each work cycle. The working cycles of these machines can be divided into a series of successive phases, the most important of which (in relation to drilling rigs) are the drilling and moving phases. During the machine movement phase, there is at least one mass acceleration period and one deacceleration period. In conventional drives this causes an increase in fuel consumption, because the energy used for accelerating the masses is converted into heat during braking and irretrievably lost. Similar phenomena occur when lifting and lowering the working unit used for drilling. The energy demand in individual phases of the work cycle usually differs from each other. In a classic drive with an internal combustion engine, the nominal engine power is selected to met the highest energy demand; meanwhile, the average energy demand in the work cycle is smaller. It follows that the combustion engine works for a significant part of time with incomplete power. As it is known, the efficiency of the drive with partial load 
is much lower, which in turn leads to an increase in fuel consumption (Mendyka et all, 2017).

The solution to this problem may be the use of an electric motor instead of an internal combustion engine as a source of drive. Due to the possibility of overloading such an engine in a limited time, it is possible to select the required drive power with a much lower value. Alternatively, you can use an electric motor with similar or higher power as the previously used internal combustion engine, which significantly improves the machine's operational capabilities.

As part of the development of the battery drive solution, the authors made a number of computer simulations and physical experiments using this type of drives. One of the tests was to determine the mechanical and electrical characteristics of the engines selected for use in the construction of a drilling rig with battery drive. The simulation analysis of such a characteristic is presented in Figure 4, while Figure 5 shows the diagram of the actual test stand.

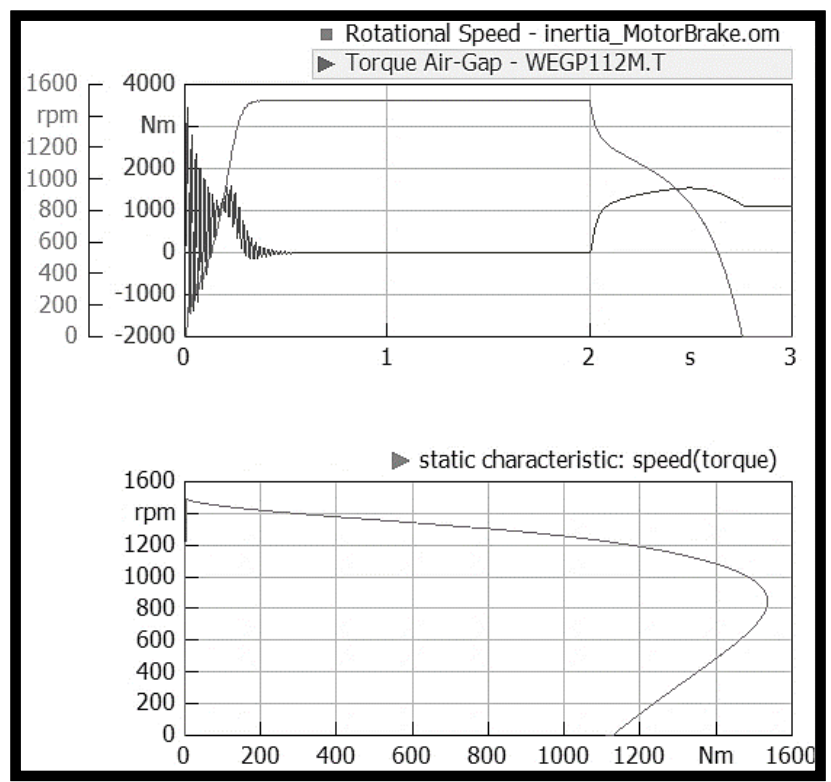

Fig. 4 Simulation of electric drive used in mining rig prototype construction

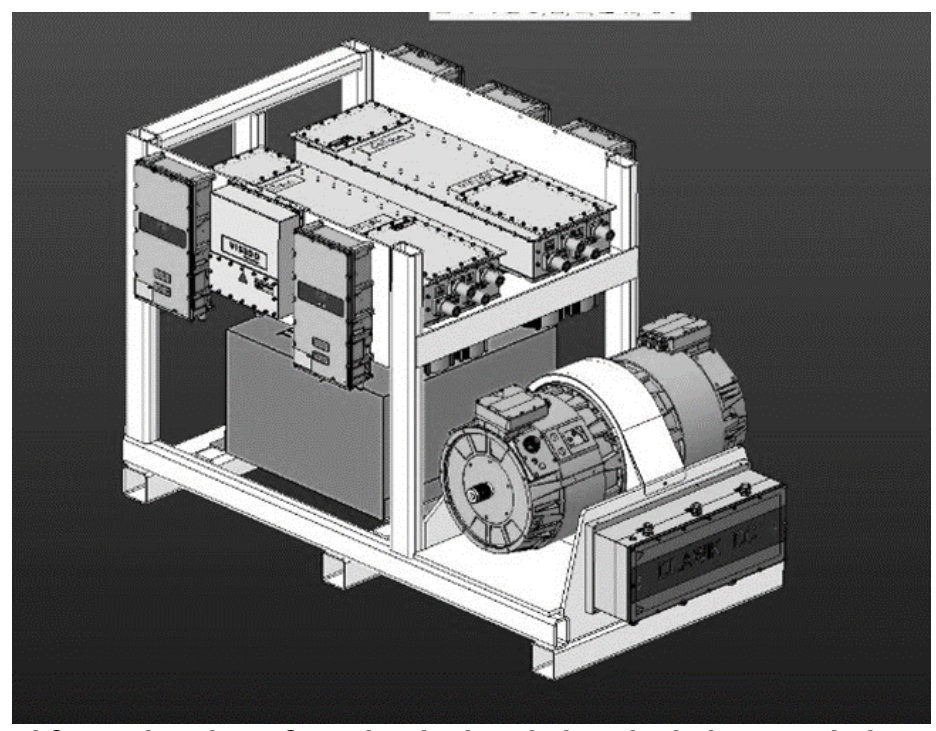

Fig. 5 Test stand for estimation of mechanical and electrical characteristics of electric drive 
The essence of the conducted model tests was the verification of physical parameters of the new (electric) drive system of the drilling rig. Model tests consisted of simulating the machine's driving system in specific field conditions. Simulation tests included, among others the following cases:

- Starting the vehicle on a level road

- Overcoming a hill (up to $15^{\circ}$ )

- Overcoming inequalities

- Braking

Due to the complexity of the structure of the drive system (mechanical, hydraulic and electrical elements), it was necessary to use the advanced multi-physical simulation software for model tests. Figures 6 and 7 present comparative tests of the machine's driveway at the most inclined slope as it is possible. In the case of the internal combustion engine, the rig was able to overcome the hill with an inclination of $15^{\circ}$, while in the case of electric drive this value reaches $18.5^{\circ}$.

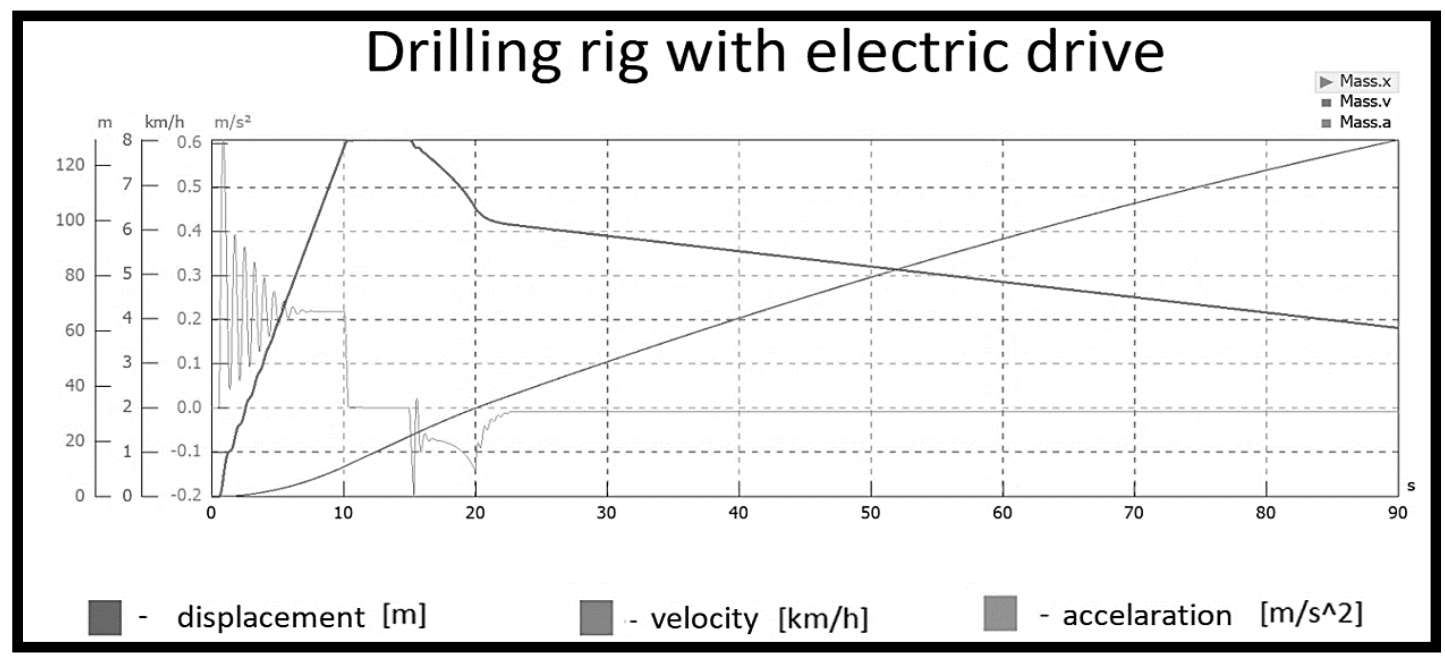

Fig. 6 Driving uphill test - maximum archived slope inclination for battery drive equaled $18.5^{\circ}$.

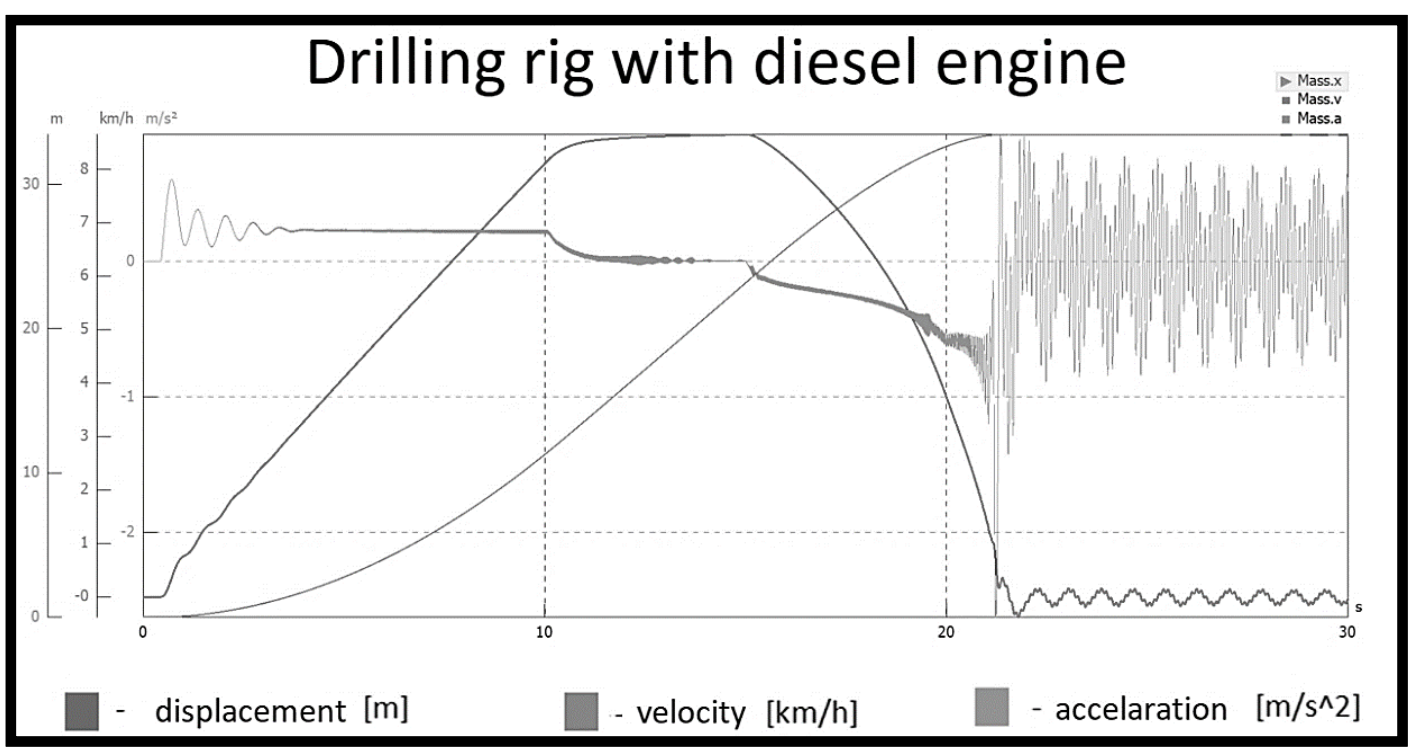

Fig. 7 Driving uphill test - maximum archived slope inclination for diesel drive equaled $15^{\circ}$ 


\title{
CONCLUSION
}

As shown in presented paper, the use of drilling rigs with electric drive has many advantages. However, it is also important to remember about the limitations resulting from their use. A thorough knowledge of the advantages and disadvantages of electric machines will allow for the introduction of new technology that will ensure trouble-free and efficient operation, and consequently will reduce the operating costs of the hard rock mines. The paper discusses the cases of mining machines with diesel and electric drive, exposing their advantages and disadvantages when working in difficult mining conditions of mining with a chamber-pillar system (Ostapów, L., Ławicki, P., 2016).

Currently, most of the self-propelled mining machines used in mining have Diesel engines. Alternative electric motors of the new generation are drive units that are increasingly adapted to work in underground mining. The electronic control systems used in these machines are recently the most evolving field in the construction of combustion engines. The result of their development is the increase of reliability of these machines, and hence the reduction of operating costs. However, despite significant achievements, diesel engines still emit significant amounts of exhaust gas and generate a lot of heat. Exhaust and heat emission worsens the working environment and requires proper ventilation in the mine (Szlązak, N., Obracaj, D., Borowski, M., 2008). This affects the high cost of ventilation, especially if the ventilation air must be additionally cooled (Wojciechowski, J.,2013).

Summing up, it should be stated that the solution of a self-propelled work machine with a modern battery drive will constitute the optimal drive structure for almost all machines operating in underground ore mines.

\section{ACKNOWLEDGMENTS}

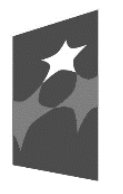

\section{European Funds \\ Smart Growth}

\author{
European Union \\ European Regional \\ Development Fund
}

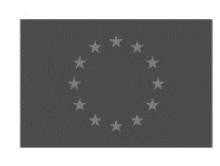

The project has been co-financed by the European Regional Development Fund under the agreement no. POIR.01.01.01-00-D011/16.

\section{REFERENCES}

Derlukiewicz, D., Karliński, J. (2004). Analiza wytrzymałościowa konstrukcji nośnej wiertnicy AMV metodą elementów skończonych. Systems: Journal of Transdisciplinary Systems Science, 9, 312-318.

Derlukiewicz, D., Karliński, J. (2012). Static and dynamic analysis of telescopic boom of self-propelled tunnelling machine. Journal of Theoretical and Applied Mechanics, 50, 47-59.

Kotwica, K. (2008). Scenarios of technological development of roadways mining in polish coal mines conditions. Gospodarka Surowcami Mineralnymi $=$ Mineral Resources Management, 24(1), 139-152.

Kotwica, K., Mendyka, P., Czajkowski, A., Ostapow, L., Kozlowski, A. (2017). The Possibility Of Battery Drive Application In Mining Drilling Rigs. International Multidisciplinary Scientific GeoConference: SGEM: Surveying Geology \& Mining Ecology Management, 17(1.3), 917-924. 
Mendyka, P., Kotwica, K., Stopka, G., Gospodarczyk, P. (2017). Dynamic and durability tests of drilling rig for narrow vein deposits. International Multidisciplinary Scientific GeoConference: SGEM: Surveying Geology \& Mining Ecology Management, 17(1.3), 275-282.

Van Mierlo, J., Maggetto, G., \& Lataire, P. (2006). Which energy source for road transport in the future? A comparison of battery, hybrid and fuel cell vehicles. Energy Conversion and Management, 47(17), 2748-2760.

Minemaster.eu, (2019). Mine Master Company Official Website. [online] Available at: http://www. minemaster.eu / [Accessed 20 May 2019].

Ostapów, L., Ławicki, P. (2016). Mechatroniczny układ sterowania dla ciągłej kontroli procesu wiercenia. Transport Przemysłowy i Maszyny Robocze, (4), 29-31.

Szlązak, N., Obracaj, D., Borowski, M. (2008). Methods for controlling temperature hazard in Polish coal mines. Archives of mining sciences, 53(4), 497-510.

Wojciechowski, J. (2013). Application of the Gmc-1000 and Gmc-2000 Mine Cooling Units for Central Air-Conditioning in Underground Mines. Archives of Mining Sciences, 58(1), 199-216.

\begin{abstract}
.
The article presents the structure of the battery drive of a self-propelled mining vehicle on the example of a drilling rig, used in the room-pillar system of copper ore exploitation. Such solutions, due to the ore mining in increasingly difficult operating conditions, are becoming more and more popular in the world. The main assumptions required for the synthesis of this type of drive were indicated, as well as the adopted structure of such a solution was described. The selection of the appropriate drive structure determines the final work characteristics of the self-propelled mining vehicle, and thus the actual suitability of such a machine for use in mining conditions. The paper also details the main technological advantages of this type of drive over classic internal combustion drives.
\end{abstract}

Keywords: drilling rig, bolting rig, battery drive, hard rock mining, electromobility 